\title{
Reeling In Outsourcing: Evaluating Supply Chain Risk And Reward Under Economic Uncertainty
}

Roberta S. Russell, Virginia Polytechnic Institute and State University, USA Marilyn Smith, Winthrop University, USA

\begin{abstract}
In today's climate of economic uncertainty, companies that have relied on outsourcing in the past to curtail costs are increasingly "reeling in" their outsourcing decision to more appropriately balance supply chain risk and reward. This paper provides a review of the literature on reversing supply chain outsourcing and frames the sourcing decision in terms of multiple options, including multi- sourcing, near sourcing, and in-sourcing. A decision tree model is presented to aid the decision maker in evaluating the expected value of various sourcing decisions when risks and returns are explicitly considered. Trends and conditions that influence the outsourcing decision are also discussed.
\end{abstract}

Keywords: outsourcing, supply chain, risk, near sourcing, in-sourcing, decision tree

\section{INTRODUCTION}

$\mathrm{n}$ the past ten years, volumes have been written in trade magazines, academic journals, and books about supply chain management and global outsourcing. In their recent comprehensive search of the literature Hult and Chabowski (2008) found 72, 003 citations on sourcing with 56, 581 of the citations from 20032007. Most of the research has dealt with supply chain strategy, partner selection, and implementation, with only a cursory mention of monitoring performance after implementation. However, outsourcing decisions are highly sensitive to changes in economic, environmental, political and competitive conditions. And the original outsourcing decision may not have adequately assessed the total costs of outsourcing. What happens then? How does an organization reel in outsourcing that is not performing at an acceptable level? Little is written about how to reel in an underperforming outsource decision, perhaps because the loss of re-building the internal capacity would be more expensive than incurring the unexpected extra costs of the outsourcing, or because firms are reluctant to admit strategic errors. Yet, companies who sought outsourcing as a panacea to cost pressures and global demand have begun to re-evaluate their outsourcing strategies in light of fuel cost volatility, complex distribution requirements, quality problems, security risks and economic uncertainty. This paper reviews the literature on reversing supply chain outsourcing and outlines the basis of a model for reshaping outsourcing strategies where risks and returns are explicitly considered.

\section{LITERATURE REVIEW}

With the audience of this paper in mind, the literature review begins with the August 2008 Decision Sciences, which was a special issue on sourcing decisions and includes Hult and Chabowski's comprehensive literature review. Key points from these articles are given in Table 1. Hult and Chabowski (2008) noted that outsourcing performance appraisal became "stronger" in the articles published in 2003-2007 compared to the articles published 1998-2002. They also suggested future research on managerial "misperceptions in developing supply chain resources," which implies that outsourcing decisions may need to be changed. As shown in Table 1, only the first three articles explicitly incorporate the concept of performance review. Ang and Inkpen (2008) provide a list of items to measure cultural intelligence. As part of cultural intelligence they suggest the company should have 
a system for exiting from offshore contracts "with minimum disruption." Salimath, Cullen, and Umesh (2008) explain how the structure (configuration) of entrepreneurial firms can change over time and how firm structure impacts the performance of outsourcing decisions. Performance review is implied in the research by Beugre and Acar (2008), which discusses the importance of cross-border relationships on understanding and effectiveness.

Sia, Koh and Tan (2008) address the concept of exiting from an outsourcing arrangement. Using an empirical study of 171 outsourcing projects in Singapore, they expand on previous search by Tan and Sia (2006) concerning flexibility in outsourcing. Their dimensions of flexibility are robustness, modifiability, new capability, and ease of exit, with ease of exit including moving outsourced services to another vendor or bringing them back inhouse. The factors that they found to positively impact ease of exit were enhancing product maturity, retaining inhouse competence, multiple sourcing (Levina and Su, 2008), vendor inoperability (Jiang, 2008), and proactively sensing flexibility and new capability (Ang, 2008). In addition, they found that while a strong relationship with the supplier enhanced robustness, modifiability, and new capability, it had a negative impact on the ability to exit. The paper appears to be groundbreaking in addressing the exit issues, but the authors recognize the limits of the study and suggest more empirical work, especially in the United States.

In addition to the articles reviewed by Hult et.al., other pertinent research includes a recent paper by Bengtsson and Berggren (2008) comparing the outsourcing decisions of Nokia and Ericsson. The authors used interviews with several managers over a four year period, as well as internal information and public information about the companies. Both companies had followed the telecom industry trend of outsourcing. First, the paper presents two outsourcing models. The horizontally integrated model has the original equipment manufacturer (OEM) retaining some of its processes in-house. The vertically divided model has all of its production transferred to contract manufactures. Nokia followed the vertically divided model by getting rid of all of its manufacturing capacity. Ericsson intended to follow the vertical divided model, but a downturn in the industry in 2005-2006 caused Ericsson to re-evaluate the decision. They decided to let their outsourcing contracts expire and "in-source" or bring the work back inside the company. Some of the key components in the decisions to in-source were miniaturization and automation, transfer costs, lead times, and logistics issues, reduced product standardization, and supply chain control. This case is a landmark work that provides insight into the pitfalls of outsourcing and provides an example of how one company successfully changed their strategy.

Simchi-Levi, et. al. (2008) report that the cost of logistics, which increased 52\% from 2002 to 2007, is forcing many companies to revisit their outsourcing decisions. The article predicts that companies will move manufacturing closer to their markets, reverse course from a pull to a push system of production, ship in bulk on slower modes of transportation (with a resulting increase in inventory levels), and bring home low profit margin/mature products or those that are heavy, large, bulky or expensive to move and inventory.

Capell (2008) describes the rapid-fire supply chain of Inditex's Zara chain of retail clothing. Zara's niche on the leading edge of fashion is reinforced by a supply chain that moves new merchandise from the designer's sketch pad to stores in less than two weeks. To reach this speed to market, they produce half of their merchandise in Spain, Portugal, and Morocco, and then pay air freight for the small shipments to the European stores. The additional money for labor and shipping is recovered by not having leftover merchandise that is discounted. However, they do outsource the production of basics, such as T-shirts, to Eastern Europe, Africa, and Asia.

Goel, Moussavi, and Srivatsan (2008) with McKinsey \& Company have recently suggested that due to rising oil costs, currency valuations and shifting wage rates, organizations should rethink their offshore production decisions. They used data gathered from company web sites, Economist Intelligence Unit, FedEx, and their internal organizational data to develop a breakeven analysis for four products -- a high-end server, a mid-range server, a mid-range copier, an assembled television, and an Ethernet switch. Then they considered whether to produce each product in the U.S., Mexico, or China. Surprisingly, the assembled television and mid-range copier would be cheaper to produce in the U.S. The study ends with a recommendation for a more precise estimate of supply chain costs to include the cost of the raw materials, inventory costs, managing product returns, reworking errors, incremental financing, and exchange-rate risks. 
Table 1. Key Points and Conclusions from Sourcing Literature

\begin{tabular}{|c|c|c|}
\hline Authors & Title & Key Points and Conclusions \\
\hline $\begin{array}{l}\text { Hult and } \\
\text { Chabowski }\end{array}$ & $\begin{array}{l}\text { Sourcing Research as an Intellectual Network } \\
\text { of Ideas }\end{array}$ & $\begin{array}{l}\text { Grouped previous research into topic clusters and compared } \\
\text { changes in cluster from 1998-2003 and 2003-2007. The } \\
\text { importance of performance assessment increased. }\end{array}$ \\
\hline $\begin{array}{l}\text { Ang and } \\
\text { Inkpen }\end{array}$ & $\begin{array}{l}\text { Cultural Intelligence and Offshore } \\
\text { Outsourcing Success: A Framework for } \\
\text { Firm-Level Intercultural Capability }\end{array}$ & $\begin{array}{l}\text { Since cultural intelligence is a requirement for successful } \\
\text { international outsourcing, they suggest research on firm } \\
\text { level cultural intelligence, as well as how cultural } \\
\text { intelligence relates to performance outcomes. }\end{array}$ \\
\hline $\begin{array}{l}\text { Salimath, } \\
\text { Cullen, and } \\
\text { Umesh }\end{array}$ & $\begin{array}{l}\text { Outsourcing and Performance in } \\
\text { Entrepreneurial Firms: Contingent } \\
\text { Relationships with Entrepreneurial } \\
\text { Configurations }\end{array}$ & $\begin{array}{l}\text { The configuration of the firm impacts the benefits of } \\
\text { outsourcing, so that as the firm changes over time, managers } \\
\text { need to reevaluate their outsourcing strategies. }\end{array}$ \\
\hline $\begin{array}{l}\text { Jiang, Yao, and } \\
\text { Feng }\end{array}$ & $\begin{array}{l}\text { Valuate Outsourcing Contracts from } \\
\text { Vendors' Perspective: A Real Options } \\
\text { Approach }\end{array}$ & $\begin{array}{l}\text { This article acknowledges that vendors may accept contracts } \\
\text { to cover lost opportunity cost and the renewal process. }\end{array}$ \\
\hline $\begin{array}{l}\text { Sia, Koh, and } \\
\text { Tan }\end{array}$ & $\begin{array}{l}\text { Strategic Maneuvers for Outsourcing } \\
\text { Flexibility: An Empirical Assessment }\end{array}$ & $\begin{array}{l}\text { Previous research on ease of exiting is expanded, with } \\
\text { conclusions that retention of in-house competence and } \\
\text { proactive sensing of changes in the industry are key } \\
\text { elements. }\end{array}$ \\
\hline $\begin{array}{l}\text { Beugre and } \\
\text { Acar }\end{array}$ & $\begin{array}{l}\text { Offshoring and Cross-Border } \\
\text { Interorganizational Relationships: A Justice } \\
\text { Model }\end{array}$ & $\begin{array}{l}\text { The justice model helps explain cross-border relationships } \\
\text { in a way that can improve effectiveness through better of } \\
\text { understanding of different cultures. }\end{array}$ \\
\hline $\begin{array}{l}\text { Goo, Huang, } \\
\text { and Hart }\end{array}$ & $\begin{array}{l}\text { A Path to Successful IT Outsourcing: } \\
\text { Interaction Between Service-level Agreement } \\
\text { and Commitment }\end{array}$ & $\begin{array}{l}\text { In service-level agreements, the interaction of commitment } \\
\text { with functional, strategic, and technological benefits is } \\
\text { complex and may reduce the technological benefits. }\end{array}$ \\
\hline $\begin{array}{l}\text { Rossetti and } \\
\text { Choi }\end{array}$ & $\begin{array}{l}\text { Supply Management Under High Goal } \\
\text { Incongruence: an Empirical Examination of } \\
\text { Disintermediation in the Aerospace Supply } \\
\text { Chain }\end{array}$ & $\begin{array}{l}\text { This research looks at a modified supply chain where tier } \\
\text { one or tier two suppliers provide replacement parts directly } \\
\text { to maintenance facilities, by passing the original equipment } \\
\text { manufacturer. }\end{array}$ \\
\hline Levina and $\mathrm{Su}$ & $\begin{array}{l}\text { Global Multi-sourcing Strategy: The } \\
\text { Emergence of a Supplier Portfolio in } \\
\text { Services Offshoring }\end{array}$ & $\begin{array}{l}\text { This case focuses on the firm's sourcing strategy and } \\
\text { suggests that having a smaller number of suppliers may } \\
\text { negatively impact the expected benefits of multi-sourcing. }\end{array}$ \\
\hline $\begin{array}{l}\text { Tangpong, } \\
\text { Michalisin, and } \\
\text { Melcher }\end{array}$ & $\begin{array}{l}\text { Toward a Topology of Buyer-Supplier } \\
\text { Relationships: A Study of the Computer } \\
\text { Industry }\end{array}$ & $\begin{array}{l}\text { When trust and cooperation (i.e., relationalism) are high, } \\
\text { then high supplier dependence can result in operational } \\
\text { efficiencies, but low supplier dependence can result in } \\
\text { higher innovation. }\end{array}$ \\
\hline
\end{tabular}

\section{DECISION TREE MODEL}

A generic macro model incorporating risk and recovery is proposed for assessing outsourcing decisions. The decision tree in Figure 1 captures some of the concepts discussed above concerning outsourcing strategies. The tree depicts three main sourcing options, in-sourcing, near sourcing and global outsourcing, each with several optional branches.

In-sourcing, in our context, is bringing production back in-house. This does not have to be an all or nothing decision, just as Ericsson maintained some of its capabilities, while it outsourced some production (Bengtsson, 2008). Similarly, a university could maintain all the facilities and equipment associated with food services for the campus, but outsource the actual food preparation process. For smaller organizations, the options may only be outsource all production or outsource labor.

Near sourcing refers to the decision to use local suppliers or suppliers within the home country or neighboring region for part or all of production. There is a renewed interest in bringing the supply chain closer to home in the current economic downturn for the following reasons. Companies faced with drastic cost cutting may 
liquidate their in-house production assets and labor in favor of contracting out production to a supplier who would assume the risks of a shaky economy. While this would seem to be an ideal solution, the cost economies of smaller orders (due to weak consumer demand) may erase some of the labor advantages of outsourcing, and the distance of an extended supply chain may create other problems. As lead time and variability increase, so do inventory levels and other buffers of demand and supply uncertainty. Tying up cash in inventory may not be financially possible when lines of credit are more difficult to obtain, and additional inventory may not be advisable when demand is tentative. Fluctuations in currency exchange rates may also be hard to predict with disastrous results in a cashstarved economy. Table 2 lists these issues and others in outsourcing during an economic downturn. The near sourcing trend is already evident in the shift of production from Asia to Central America by such companies as WalMart, Dell, IBM, P\&G, and Sara Lee (Schwartz, 2008).

In the decision tree, national or regional companies are distinguished from global companies because it is assumed that the risks would be higher if the outsourcing were global, and the cost of reeling in outsourced activities would be greater. The empirical research by Sia, et al. (2008) found that maintaining some in-house competence made exit from a supplier easier. This is related to the recent finding of Levina and $\mathrm{Su}$ (2008) that a larger number of suppliers may provide a better fit with strategic objectives than a limited supply base.

If a firm uses global sourcing for production, they also have the same option of maintaining some national production, retaining some facilities, or outsourcing all production. Recent reports that Dell is developing plans to sell all of its manufacturing facilities would place it in the box at the bottom of the decision tree (Scheck, 2008). Russell and Taylor (2009) summarized the various decisions and changes in strategies that New Balance has made, including keeping some production in the U.S., cancelling an international manufacturing contract after the supplier was caught producing and selling counterfeit products, and the company's continuing efforts to "balance" foreign and domestic production.

Each branch of the decision tree shown in Figure 1 would have a risk and cost associated with it. Normally, we would expect risk to increase and cost to decrease moving down the decision tree. This assumes that risk increases with distance as more of a firm's capacity is outsourced and that low labor costs would more than compensate for increased transportation and coordination costs. The cost assumption is being called into question at least in some industries (Goel, 2008). However, there is some empirical evidence to support the assumption of increased risk. Moving to a global supplier may make it more difficult to accurately check references and verify the capacity of the supplier, hence making the risk greater (Schwartz, 2008). Issues of cultural intelligence become more significant and more difficult moving from local to global outsourcing (see Ang and Inkpen, 2008). The challenges that Beugre and Acur (2008) presented in their assessment of cross-border inter-organizational relationships also increase the risk in global outsourcing. It should be noted that the decision tree is single tier, and does not capture the multiple levels and complexity of Dell outsourcing production to Solectron, and Solectron producing the product at a facility that it owns, but using outsourced labor.

While costs of production, transportation, coordination and inventory can be obtained, risk is more difficult to assess. Aberdeen (2006) found that $82 \%$ of businesses in its survey were concerned about supply chain risk, but only $11 \%$ were managing risk. A survey of worldwide executives of larger firms by McKinsey Quarterly (2006) indicated that $28 \%$ used rough quantitative estimates to assess risk, $34 \%$ used qualitative or intuitive methods, and $24 \%$ had no formal assessment of supply chain risk at all. Only $15 \%$ indicated that they use detailed cash flow models to assess supply chain risk. The survey also asked about corporate standards for mitigation of supply chain risk and the enforcement of the standards. Only $46 \%$ of the respondents have standards in place, but only $23 \%$ reported that these standards were enforced very well. 
Figure 1. Outsourcing Decision Tree

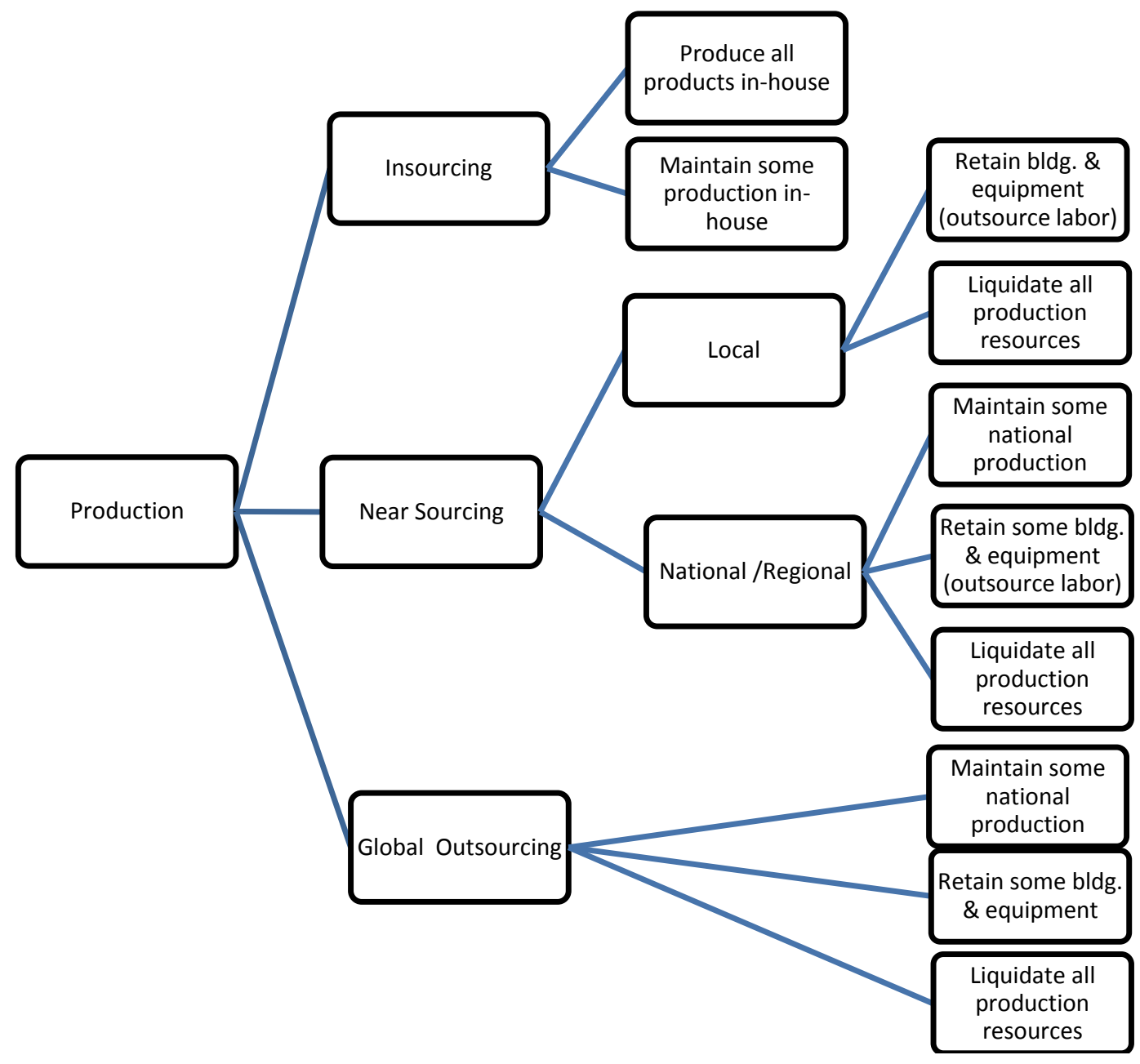

Table 2. Outsourcing Issues and Trends in an Economic Downturn

\begin{tabular}{|l|l|}
\hline \multicolumn{1}{|c|}{ Economic Condition } & \multicolumn{1}{c|}{ Supply Chain Effect } \\
\hline Weak and unpredictable demand & Flexibility important \\
\hline Limited windows of demand opportunity & Speed-to-market important \\
\hline Reduced cash for investment in inventory & Difficult to obtain loans or lines of credit \\
\hline Increased transportation costs & Smaller, more frequent orders; shorter supply chain; near sourcing \\
\hline Increased cost of outsourced production & Reduced economies of scale; smaller orders; consider in-sourcing \\
\hline Unpredictable currency exchange rates & Hedge with multiple locations; move to more stable economies \\
\hline $\begin{array}{l}\text { Belt tightening leaves less money to verify quality } \\
\text { of goods produced }\end{array}$ & $\begin{array}{l}\text { Looser control and cost pressures may induce suppliers to cut corners; } \\
\text { liability risk increases }\end{array}$ \\
\hline Long term viability of suppliers at risk & One-time contracts, quick delivery; multi-source \\
\hline Long term viability of manufacturers at risk & $\begin{array}{l}\text { Suppliers may demand payment before goods are delivered; refuse } \\
\text { contract or add risk penalty }\end{array}$ \\
\hline Banks may not have monies to lend & Cancelled orders; \\
\hline Government interventions in economic crisis & $\begin{array}{l}\text { Near shore or in-source if offshore production penalized or onshore } \\
\text { production incentivized }\end{array}$ \\
\hline Need to share risks of economic downturn & $\begin{array}{l}\text { Spread risk among multiple suppliers; renegotiate contract terms; share } \\
\text { resources }\end{array}$ \\
\hline
\end{tabular}




\section{CONCLUSIONS}

While AMR Research reports that $90 \%$ of manufacturers surveyed outsource at least some of their production, over half of those experienced an increase rather than decrease in cost. This is in part due to underestimated costs of transportation, holding costs for extra inventory, unplanned air freight, and other hidden costs due to variable quality, counterfeiting, obsolescence, security problems, and management complexity. A more realistic assessment of the costs of outsourcing must include an evaluation of risk.

Incorporating risk in outsourcing decisions and the cost to alter or reverse that decision into an overall sourcing model would help the organization make better long-term decisions. The risk could then be incorporated into a comprehensive cost model that would track shifts in the global economy to indicate when changes in outsourcing should be made. In this paper, we presented a generalized decision tree to begin the evaluation of sourcing options from in-sourcing to near-sourcing to global outsourcing.

Uncertain economic times and volatile markets demand a higher level of scrutiny and due diligence of outsourcing agreements. While exiting an outsourcing arrangement may involve penalties, both company and vendor may benefit from a re-negotiation of terms that frees up resources and either reduces or increases commitment levels (Murti, 2009). Profit-sharing, risk-sharing, re-structured financing and performance incentives may be on the table. The tendency of businesses to react by either "freezing" new initiatives of any type or rushing headlong into "slash and burn" outsourcing should be avoided in favor of developing a sourcing strategy that explicitly considers costs, risk and flexibility. Companies worldwide are beginning to reshape supply chain strategies with multi-sourcing (smaller contracts between several suppliers), shorter contracts, near-sourcing, and flatter network reconfigurations.

\section{AUTHOR INFORMATION}

Roberta Russell is a Professor of Business Information Technology in the Pamplin College of Business at Virginia Tech and Director of the Center for Services Science, Quality and Innovation (SSQI). Dr. Russell conducts research in operations management, service operations, quality management and supply chains. She has published in Decision Sciences, IIE Transactions, Journal of Operations Management and others. She is also co-author of Operations Management: Creating Value Along the Supply Chain published by Wiley. Dr. Russell is a member of DSI, APICS, ASQ, and IIE. She is a certified fellow (CFPIM) of APICS and a supply chain management professional (CSCP).

Marilyn Smith is a Professor of Management at Winthrop University. She has both academic and industry experience in quality control, inventory control and process improvement with companies such as Holston Defense, Burroughs, and Solectron. In addition to being an active researcher, Dr. Smith has served six years as an Examiner for the Malcolm Baldrige National Quality Award and as a Senior Examiner and Judge of the S.C. Governor's Quality Award. She is also a recipient of the Society of Manufacturing Engineers Outstanding Young Manufacturing Engineer Award, and the Winthrop University Community Service Award.

\section{REFERENCES}

1. Ang, S., \& Inkpen, A. C. (2008). Cultural Intelligence and Offshore Outsourcing Success: A Framework of Firm-Level Intercultural Capability. Decision Sciences. 39(3), 337-358.

2. Bengtsson, L. \& Berggren, C. (2008). The integrator's new advantage - the reassessment of outsourcing and production competence in a global telecom firm. European Management Journal. 26, 314-324.

3. Beugré, C. D., \& Acar, W. (2008). Offshoring and Cross-Border Interorganizational Relationships: A Justice Model. Decision Sciences. 39(3), 445-468.

4. $\quad$ Capell, Kerry. (2008). Zara Thrives by Breaking All the Rules. Business Week. October 20, 2008.

5. $\quad$ Enslow, B. (2006) “Global Supply Chain Benchmark Report,” Aberdeen Group, June 2006.

6. Goel, A., Moussavi, N., \& Srivatsan, V. (2008) Time to rethink offshoring? The McKinsey Quarterly, September 2008. 
7. Goo, J., Huang, C. D., \& Hart, P. (2008). A Path to Successful IT Outsourcing: Interaction Between Service-Level Agreements and Commitment. Decision Sciences. 39(3), 469-506.

8. Hult, G. T. M., \& Chabowski, B. R. (2008). Sourcing Research as an Intellectual Network of Ideas. Decision Sciences. 39(3), 323-336.

9. Jiang, B., Yao, T., \& Feng, B. (2008). Valuate Outsourcing Contracts from Vendors' Perspective: A Real Options Approach. Decision Sciences. 39(3), 383-406.

10. Krishnan, M. \& Shulman, J. (2007) Reducing supply chain risk. McKinsey Quarterly, 1, 10-13.

11. Levina, N., \& Su, N. (2008). Global Multisourcing Strategy: The Emergence of a Supplier Portfolio in Services Offshoring. Decision Sciences. 39(3), 541-570.

12. Murti, M. (2009), "Making Sourcing Decisions in an Economic Downturn," Financial Post, PricewaterhouseCoopers, January 5, 2009.

13. Rossetti, C. and Choi, T. Y. (2008). Supply Management Under High Goal Incongruence: An Empirical Examination of Disintermediation in the Aerospace Supply Chain. Decision Sciences. 39(3), 507-540.

14. Russell, R. \& Taylor, B. (2009). Operations Management: Creating Value Along the Supply Chain . Hoboken, N.J.: John Wiley \& Sons, Inc.

15. Sadlovska, V., M. Spinks, and R. Shecterle (2008) "Supply Chain Risk Management: Building a Resilient Global Supply Chain," Aberdeen Group, July 2008.

16. Salimath, M. S., Cullen, J. B., and Umesh, U.N. (2008). Outsourcing and Performance in Entrepreneurial Firms: Contingent Relationships with Entrepreneurial Configurations. Decision Sciences. 39(3), 359-382.

17. Sia, S. K., Koh, C., and Tan, C. (2008). Strategic Maneuvers for Outsourcing Flexibility: An Empirical Assessment. Decision Sciences. 39(3), 407-444.

18. Scheck, J. (2008) Dell plans to sell factories in effort to cut costs, The Wall Street Journal, Sept 5, 2008.

19. Schwartz, E. (2008, August 25). Painful lessons from IT outsourcing gone bad. Infoworld.com. Retrieved September 2, 2008.

20. $\quad$ Shister, N. "Near-Sourcing," World Trade, January 1, 2008.

21. Simichi-Levi, D., Nelson, D., Mulani, N. and Wright, J. (2008). Crude Calculations. Wall Street Journal. September 22, 2008.

22. Tan, C. and Sia, S.K.(2006). Managing flexibility in outsourcing. Journal of the Association for Information Systems, 7(4), 179-206.

23. Tangpong, C., Michalisin, M. D., and Melcher, A. J. (2008). Toward a Typology of Buyer-Supplier Relationships: A Study of the Computer Industry. Decision Sciences. 39(3), 571-594.

24. Yuva, J. (2009). Shifting Globalization into Reverse. Inside Supply Chain Management. 20 (2), $20-23$. 


\section{NOTES}

